C. Colombo - M. Delvecchio $\cdot$ C. Zecchino •

M. F. Faienza - L. Cavallo - F. Barbetti - The Early

Onset Diabetes Study Group of the Italian Society

of Paediatric Endocrinology and Diabetology

\title{
Transient neonatal diabetes mellitus is associated with a recurrent (R201H) KCNJ11 (KIR6.2) mutation
}

Received: 5 May 2005 / Accepted: 27 July 2005 / Published online: 5 October 2005

(C) Springer-Verlag 2005

Keywords GLP-1 - Insulin secretion · KCNJ11 - KIR6.2 • Permanent neonatal diabetes $\cdot$ Transient neonatal diabetes

To the Editor: Neonatal diabetes mellitus (NDM) is a rare, monogenic form of diabetes currently defined as insulinrequiring hyperglycaemia within the first 3 months of life [1]. Neonatal diabetes can be either permanent (PNDM), requiring life-long insulin treatment, or transient (TNDM), the latter usually subsiding within 12 months of onset. In some patients with TNDM a relapse of diabetes can occur during adolescence. Recently, activating mutations of KCNJ11 (previously known as KIR6.2), encoded by the $K C N J 11$ gene, have been found to result in the permanent form of this condition [2]. In addition, KCNJ11 mutations with a milder effect can also give rise to remitting, re-

C. Colombo · F. Barbetti

Laboratory of Molecular Endocrinology and Metabolism,

Bambino Gesù Children's Hospital,

Scientific Institute (IRCCS),

Rome, Italy

M. Delvecchio · C. Zecchino - M. F. Faienza · L. Cavallo Department of Biomedicine of Developing Age,

Paediatric Endocrinology and Diabetes Unit, University of Bari,

Bari, Italy

F. Barbetti $(\square)$

Department of Laboratory Medicine,

Policlinico Tor Vergata University Hospital,

Rome, Italy

e-mail: mody.2@libero.it

Tel.: +39-068-0319058

Fax: +39-068-0319054

F. Barbetti

Laboratory of Molecular Endocrinology and Metabolism,

Biomedical Scientific Park of Rome S Raffaele,

Via di Castel Romano, 100,

00128 Rome, Italy lapsing, or transient neonatal diabetes [3]. In this study, the genetic basis of a case of neonatal diabetes with an atypical clinical course was investigated.

The proband (referred to as nd-BA/2) is now 20 years old, and is the only child born to healthy, unrelated parents. She was delivered at term with a weight of $2,300 \mathrm{~g}$ (10th centile). Her random plasma glucose was found to be elevated during the 2 nd day of life, with values ranging from 10.0 to $16.6 \mathrm{mmol} / \mathrm{l}$ without ketonuria.

During the first 5 weeks of life the child was in good general health and showed a regular increase of body weight despite high plasma glucose levels. Fasting C-peptide was detectable (149 pmol/1, reference values: 178-680) and tests for anti-beta-cell autoantibodies were negative. Insulin therapy was not begun until the age of 37 days, when due to severe hyperglycaemia $(32 \mathrm{mmol} / \mathrm{l})$, ketonuria and a failure to thrive, a daily dose of $1.1 \mathrm{U} \mathrm{kg}^{-1}$ day $^{-1}$ was administered. After stabilisation, insulin treatment was progressively reduced and stopped at the age of 29 months because of good metabolic control and episodes of hypoglycaemia. Two OGTTs performed 5 and 17 months after insulin withdrawal showed that the patient had progressed from IGT to normal glucose tolerance (Table 1). $\mathrm{HbA}_{1} \mathrm{c}$, determined once a year during the following 4 years, was always below $7 \%(4.1-6.3 \%)$.

An OGTT performed at the age of 7 years and 7 months showed a recurrence of diabetes (Table 1), and 6 months later insulin therapy was re-established $\left(0.8 \mathrm{U} \mathrm{kg}^{-1}\right.$ day $\left.^{-1}\right)$ because of persistently high $\mathrm{HbA}_{1} \mathrm{c}$ values $(11.5 \%)$. At around the same age anti-gliadin autoantibodies were detected in the absence of clinical symptoms. Coeliac disease was confirmed by biopsy and the child was put on a glutenfree diet.

In November 2004, informed consent for genetic analysis was obtained from the proband. The intronless KCNJ11 gene was amplified in three overlapping fragments $(B, C$ and $\mathrm{D}$ ), with a primer pair previously described for $\mathrm{B}$ and $\mathrm{C}$ fragments [4] and modified for the D fragment (D forward: $5^{\prime}$ ceg ctg atc atc tac cat gtc 3'; D reverse: $5^{\prime}$ tac cac atg gtc cgt gtg tac $3^{\prime}$ ). We identified a heterozygous R201H mutation $(\mathrm{c} .602 \mathrm{G} \rightarrow \mathrm{A}$ ) that arose de novo in the patient. 
Table 1 Test results for patient nd-BA/2 at various ages
$M M$ mixed meal, $P G$ plasma glucose (mmol/l), IRI immunoreactive insulin (pmol/l), C-pep C-peptide (pmol/l), N.a. not available

${ }^{\mathrm{a}}$ Tests performed during chronic glibenclamide therapy

\begin{tabular}{|c|c|c|c|c|c|c|c|}
\hline \multirow[t]{2}{*}{ Age } & \multirow[t]{2}{*}{ Test } & \multirow[t]{2}{*}{ Value measured } & \multicolumn{5}{|c|}{ Time of sample in minutes } \\
\hline & & & 0 & 30 & 60 & 120 & 180 \\
\hline \multirow[t]{3}{*}{2 years 9 months } & \multirow[t]{3}{*}{ OGTT } & PG & 4.5 & 11.4 & 10 & 8.4 & 6.5 \\
\hline & & C-pep & 132.4 & 364.1 & 279.9 & 430.3 & 31.7 \\
\hline & & IRI & 47.3 & 88.2 & 87.5 & 64.6 & 60.9 \\
\hline \multirow[t]{2}{*}{4 years 1 month } & \multirow[t]{2}{*}{ OGTT } & PG & 6.0 & 8.8 & 12.2 & 7.2 & 8.0 \\
\hline & & C-pep & 132.4 & 397.2 & 397.2 & 331.0 & 264.8 \\
\hline \multirow[t]{3}{*}{7 years 6 months } & \multirow[t]{3}{*}{ OGTT } & PG & 7.2 & 14.3 & 9.6 & 11.7 & 9.4 \\
\hline & & C-pep & 66.2 & 231.7 & 231.7 & 264.8 & N.a. \\
\hline & & IRI & $<35.8$ & 60.9 & 43.0 & 40.9 & 37.3 \\
\hline \multirow[t]{3}{*}{19 years 9 months $^{\mathrm{a}}$} & \multirow[t]{3}{*}{$\mathrm{MM}^{\mathrm{a}}$} & PG & 6.6 & 10.8 & 11.6 & 12.1 & N.a. \\
\hline & & C-pep & 860.6 & 1754.3 & 1754.3 & 1522.6 & N.a. \\
\hline & & IRI & 12 & 35 & 29 & 31 & N.a. \\
\hline \multirow[t]{5}{*}{20 years $^{\mathrm{a}}$} & \multirow[t]{3}{*}{ OGTT $^{\mathrm{a}}$} & PG & 5.6 & 10.0 & 12.8 & 13.8 & 14.7 \\
\hline & & C-pep & 1026.1 & N.a. & 1621.9 & 2250.8 & 2019.1 \\
\hline & & $\underline{\text { IRI }}$ & 13 & N.a. & 15 & 26 & 24 \\
\hline & & & \multicolumn{5}{|c|}{ Time of sample in minutes } \\
\hline & & & 0 & 1 & 3 & 10 & 15 \\
\hline \multirow[t]{2}{*}{7 years 6 months } & \multirow[t]{2}{*}{ IVGTT } & PG & N.a. & N.a. & N.a. & N.a. & N.a. \\
\hline & & IRI & $<35.8$ & 78.9 & 74.6 & 74.6 & 77.5 \\
\hline \multirow[t]{3}{*}{19 years 8 months } & \multirow[t]{3}{*}{ IVGTT } & PG & 11.1 & 22.1 & 22.6 & 19.1 & 19.6 \\
\hline & & C-pep & 231.7 & 165.5 & 264.8 & 264.8 & 231.7 \\
\hline & & IRI & 10 & 10 & 12 & 15 & 11 \\
\hline \multirow[t]{3}{*}{19 years 9 months ${ }^{\mathrm{a}}$} & \multirow[t]{3}{*}{ IVGTT $^{\mathrm{a}}$} & PG & 9.5 & 19.5 & 20.5 & 19.2 & 18.9 \\
\hline & & C-pep & 1158.5 & 897.3 & 1290.9 & 959.9 & 1059.2 \\
\hline & & IRI & 16 & 23 & 14 & 16 & 16 \\
\hline
\end{tabular}

When on chronic (1 month) glibenclamide therapy, the patient underwent three tests: IVGTT, OGTT and a mixedmeal test, with an interval of 1 week between each test. The mixed meal consisted of $1 \mathrm{~g}$ of proteins and $1 \mathrm{~g}$ of carbohydrates per $\mathrm{kg}$ body weight. A tablet of $5 \mathrm{mg}$ of glibenclamide was administered to the patient $30 \mathrm{~min}$ before the beginning of each test. The daily doses of glibenclamide before the tests were similar (from 0.33 to $0.39 \mathrm{mg} \mathrm{kg}^{-1}$ day $^{-1}$ ). Plasma glucose was determined by the hexokinase method, C-peptide and insulin were assayed by commercially available radioimmunoassay kits.

In December 2004 we attempted to wean the patient from insulin and substitute it with the sulfonylurea glibenclamide. The dosage of glibenclamide was increased in a stepwise manner to the current dose of $17.5 \mathrm{mg} /$ day $\left(0.39 \mathrm{mg} \mathrm{kg}^{-1} \mathrm{day}^{-1}\right)$, while insulin was stopped after 11 days. The results of the tests performed under glibenclamide treatment are presented in Table 1 (marked by superscript $^{\mathrm{a}}$ ). Fasting C-peptide values normalised after 1 month of glibenclamide treatment, but C-peptide secretion during IVGTT was blunted, with no increase over basal. This was similar to the results of an IVGTT performed immediately before the switch to glibenclamide (Table 1). In both tests however, the patient had fasting hyperglycaemia. In contrast, C-peptide during the OGTT and mixed meal showed a near-normal profile, with a two-fold increase of the fasting values at $60 \mathrm{~min}$ in both tests (Table 1).
The $\mathrm{R} 201 \mathrm{H}$ mutation of KCNJ11 is the most frequent genetic defect associated with cases of KCNJ11-related PNDM [2, 5-8]. Interestingly, our patient was no different, in terms of birthweight centile and time of onset of hyperglycaemia, from the 14 individuals who are known to carry the same mutation and have been reported on in the literature [2, 5-8]. Remitting and/or relapsing neonatal diabetes resulting from moderately activating mutations in KCNJ11 have also been described [3]. However, none of the ten patients carrying the $\mathrm{R} 201 \mathrm{H}$ mutation and currently older than 3 years experienced any remission of diabetes, and all were insulin-treated from the time of diagnosis (but for a single case, on tolbutamide since childhood). In proband nd-BA/2 hyperglycaemia was present at birth, but after 30 months of insulin therapy, she was assigned to diet-only treatment, which lasted for more than 5 years. Accordingly, insulin secretion in response to either an oral or intravenous glucose challenge was impaired, but detectable over the same period of time. It should be noted that the clinical course of our patient, nd-BA/2, is not even similar to 'classical' TNDM, due to defects in chromosome 6 [1]. In these patients, TNDM usually remits well before 12 months of age, returning (in about $50 \%$ of cases) when the patient is around 14 years old [1]

So what makes our patient different from others bearing the same KCNJ11 mutation? At the genetic level, we did not find any variation in the coding or promoter sequence 
of KCNJ11 that could explain the different metabolic phenotype. To date, no data are available about possible interactions between KCNJ11 functional variant E23K (moderately activating) and KCNJ11 mutations that induce neonatal diabetes. In any case, DNA sequencing showed that patient nd-BA/2 is wild-type homozygous (E23) for this variant. Interestingly, the R201H-related PNDM patient identified by Klupa et al. [8], who also showed some residual insulin secretion, was found to be homozygous for the $\mathrm{K}$ variant. Thus, at this point we can only speculate that patient nd-BA/2 may be more insulin-sensitive than other individuals with the $\mathrm{R} 201 \mathrm{H}$ mutation of KCNJ11.

In this study, we also show that sulfonylurea therapy resulted in good metabolic control of our patient $\left(\mathrm{HbA}_{1} \mathrm{c}=7.8 \%\right)$, as already reported in individuals with the same genetic defect $[5,7,8]$. Intriguingly, in patient nd-BA/2 glibenclamide treatment restored insulin secretion dynamics to an oral glucose test (or to a mixed meal), but not to the intravenous glucose challenge (although some degree of glucose toxicity could have affected C-peptide secretion during IVGTTs). It is known that oral glucose can stimulate secretion of the insulin secretagogue hormone glucagonlike peptide-1 (GLP-1) from the intestinal L cells, while intravenous glucose is ineffective. Glucose and sulfonylureas have also been reported to trigger the generation of action potentials in a GLP-1-secreting cell line, suggesting a role for $K_{\mathrm{ATP}}$ channels in this function [9]. It might, therefore, be of interest to evaluate GLP-1 secretion before and after glibenclamide treatment in patients with KCNJ11 mutation.

In conclusion, these data confirm that KCNJ11 mutations can confer a broad range of clinical presentations, and that screening of KCNJ11 gene is warranted in all patients with NDM.
Acknowledgements F. Barbetti is the recipient of Telethon grant No. GGP04264. C. Colombo is a postdoctoral fellow of Bambino Gesù Children's Hospital, IRCCS, Rome Italy.

\section{References}

1. Polak M, Shield J (2004) Neonatal and very-early-onset diabetes mellitus. Semin Neonatol 9:59-65

2. Gloyn AL, Pearson ER, Antcliff JF et al (2004) Activating mutations in the ATP-sensitive potassium channel subunit Kir6.2 gene are associated with permanent neonatal diabetes. N Engl J Med 350:1838-1849

3. Gloyn AL, Reimann F, Girard C et al (2005) Relapsing diabetes can result from moderately activating mutations in KCNJ11. Hum Mol Genet 14:925-934

4. Massa O, Iafusco D, D'Amato E et al (2005) KCNJ11 activating mutations in Italian patients with permanent neonatal diabetes. Hum Mutat 25:22-27

5. Sagen J, Raeder H, Hathout E et al (2004) Permanent neonatal diabetes due to mutations in KCNJ11 encoding Kir6.2. Patient characteristics and initial response to sulfonylurea therapy. Diabetes 53:2713-2718

6. Vaxillaire M, Populaire C, Busiah K et al (2004) Kir6.2 mutations are a common cause of permanent neonatal diabetes in a large cohort of French patients. Diabetes 53:2719-2722

7. Zung A, Glaser B, Nimri R, Zadik Z (2004) Glibenclamide treatment in permanent neonatal diabetes mellitus due to an activating mutation in Kir6.2. J Clin Endocrinol Metab 89:55045507

8. Klupa T, Edghill EL, Nazim J et al (2005) The identification of a R201H mutation in KCNJ11, which encodes Kir6.2, and successful transfer to sustained-release sulphonylurea therapy in a subject with neonatal diabetes: evidence for heterogeneity of beta cell function among carriers of the R201H mutation. Diabetologia 48:1029-1031

9. Reimann F, Gribble FM (2002) Glucose-sensing in glucagonlike peptide-1-secreting cells. Diabetes 51:2757-2763 